\title{
Acute viral bronchiolitis in South Africa: Intensive care management for severe disease
}

\author{
B M Morrow, ${ }^{1}$ PhD, BSc (Physio), PG Dipl (Health Research Ethics); C Feldman, ${ }^{2}$ MB BCh, FCP (SA), FRCP, PhD, DSc; \\ R J Green, ${ }^{3} \mathrm{PhD}, \mathrm{DSc}$ \\ ${ }^{1}$ Department of Paediatrics and Child Health, Faculty of Health Sciences, University of Cape Town, South Africa \\ ${ }^{2}$ Department of Medicine, Faculty of Health Sciences, University of the Witwatersrand, Johannesburg, South Africa \\ ${ }^{3}$ Department of Paediatrics and Child Health, Faculty of Health Sciences, University of Pretoria, South Africa
}

Corresponding author: B M Morrow (brenda.morrow@uct.ac.za)

It is estimated that $2-3 \%$ of children will be hospitalised with viral bronchiolitis during their first year of life, and a small proportion of them will have a severe course of the disease, requiring intensive care and ventilatory support. In South Africa, $20 \%$ of children admitted to a paediatric intensive care unit (PICU) had positive respiratory viral isolates (especially respiratory syncytial virus), with symptomatic respiratory disease. Rapid laboratory-based diagnosis using multiplex polymerase chain reaction is recommended to reduce overall antibiotic use in the PICU and neonatal ICU (NICU) and improve the targeted use of antibiotics (antibiotic stewardship). The mainstay of bronchiolitis management in the PICU and NICU is supportive, comprising fluid management, oxygen supplementation and/or respiratory ventilatory support, and antipyretics if needed. Non-invasive nasal continuous positive airway pressure and high-flow nasal cannula oxygen therapy are increasingly being used in children with severe bronchiolitis, and may reduce the need for intubation. Infants with bronchiolitis may have a variety of clinical presentations, which may require different ventilatory approaches. Children may present predominantly with apnoeas, air trapping and wheeze, atelectasis and parenchymal disease (in acute respiratory distress syndrome), or a combination of these. Lung-protective ventilation, using a low tidal volume pressure-limited approach, is essential to limit ventilator-induced lung injury.

S Afr Med J 2016;106(5):446-448. DOI:10.7196/SAMJ.v106i5.10436

It is estimated that $2-3 \%$ of children will be hospitalised with viral bronchiolitis during their first year of life, and a small proportion of them will have a severe course of the disease (Table 1), requiring intensive care and ventilatory support. ${ }^{[1-3]}$ Risk factors for severe disease include a history of prematurity; underlying chronic conditions such as bronchopulmonary dysplasia, neuromuscular disease, and congenital heart diseases; lack of breastfeeding; poor socioeconomic circumstances; and immunosuppression, including HIV/AIDS. ${ }^{[4]}$

\section{Aetiology and \\ co-infection}

In South Africa (SA), $20 \%$ of children admitted to a paediatric intensive care unit (PICU) were reported to have positive respiratory viral isolates, with symptomatic respiratory disease. ${ }^{[5]}$ The most common viruses occurring in the PICU context in SA are human rhinovirus, respiratory syncytial virus (RSV), adenovirus, influenza and para-influenza viruses, and human metapneumovirus (hMPV). ${ }^{[5,6]}$

The importance of human rhinovirus has previously been underestimated, but is now known to be a pathogen with the potential to cause severe disease in both PICU and neonatal ICU (NICU) populations, with a prevalence of up to $40 \%$ in emergency department and hospital settings. ${ }^{[7,8]}$ In a case controlled study of children after cardiac surgery, human rhinovirus infection was associated with a twelvefold

Table 1. Assessment of bronchiolitis severity in infants ${ }^{[4]}$

\begin{tabular}{|c|c|c|c|}
\hline Observations & $\begin{array}{l}\text { Mild } \\
\text { bronchiolitis }\end{array}$ & $\begin{array}{l}\text { Moderate } \\
\text { bronchiolitis }\end{array}$ & $\begin{array}{l}\text { Severe } \\
\text { bronchiolitis }\end{array}$ \\
\hline Feeding & Normal & Less than usual & Not interested \\
\hline $\begin{array}{l}\text { Respiratory rate, } \\
\text { breaths/min }\end{array}$ & $\begin{array}{l}<2 \mathrm{mo},>60 \\
>2 \mathrm{mo},>50\end{array}$ & $>60$ & $>70$ \\
\hline Chest wall recessions & Mild & Moderate & Severe \\
\hline Nasal flare or grunting & Absent & Absent & Present \\
\hline Oxygen saturation, $\%$ & $>92$ & $88-92$ & $<88$ \\
\hline General behaviour & Normal & Irritable & Lethargic \\
\hline
\end{tabular}

increase in the probability of extubation failure, a threefold increase in duration of PICU stay, and a twofold increase in length of hospital stay. ${ }^{[9]}$ It has been suggested that when human rhinovirus is detected by polymerase chain reaction (PCR) in symptomatic individuals, it is likely to represent true infection. ${ }^{[10]}$

hMPV has been reported in up to $19 \%$ of hospitalised SA children with respiratory tract infections (RTIs). ${ }^{[1,12]}$ hMPV is associated with significant morbidity, with similar presentation and outcome to RSV infection. ${ }^{[12]}$

In the PICU, co-infection with bacteria and other potential pathogens (e.g. fungi, Pneumocystis jirovecii) is common. ${ }^{[5]}$ Recently, nosocomial acquisition of viral RTI has been highlighted as a potentially serious problem, particularly in the context of limited cohorting and isolation facilities in SA and other develop- ing countries. ${ }^{[5,6,13,14]}$ The importance of infection control measures, including hand washing, surface cleaning, isolation, and cohorting must be emphasised to prevent nosocomial spread of respiratory viruses. ${ }^{[15]}$

Rapid laboratory-based diagnosis using multiplex PCR is recommended to reduce overall antibiotic use in the PICU and NICU and to improve the targeted use of antibiotics (antibiotic stewardship), as well as early identification of potential outbreaks to ensure containment and limit nosocomial transmission. ${ }^{[16,17]}$

\section{Management of bronchiolitis in the PICU and NICU}

The mainstay of bronchiolitis management in the PICU and NICU is supportive, compris- 
ing fluid management, oxygen supplementation and/or respiratory ventilatory support, and antipyretics if needed. ${ }^{[17,18]}$

\section{Ventilatory support}

Mechanical ventilation for bronchiolitis was first described in the 1960s, when it markedly decreased mortality associated with respiratory failure. ${ }^{[19]}$ However, numerous complications of intubation and mechanical ventilation are now described, including ventilator-induced lung injury, ventilator-associated pneumonia, and tracheal stenosis. ${ }^{[20]}$ In a prospective observational multicentre study, ${ }^{[21]}$ endotracheal intubation and mechanical ventilation were shown to cause a marked increase in pulmonary inflammation in infants with severe RSV bronchiolitis. The avoidance of intubation and invasive mechanical ventilation as far as possible is therefore optimal in terms of lung protection but they may be necessary in severe disease.

Non-invasive nasal continuous positive airway pressure (nCPAP) and high-flow nasa cannula (HFNC) oxygen therapy are increasingly being used in children with severe bronchiolitis, and may reduce the need for intubation. ${ }^{[22-24]}$ Furthermore, these technologies may provide the only form of ventilatory support in areas where children with severe bronchiolitis cannot access mechanical ventilation. ${ }^{[23]}$ nCPAP may reduce the work of breathing by preventing dynamic airway collapse, thereby potentially reducing air trapping and improving gaseous exchange, although there may also be a risk of overinflation. ${ }^{[25]}$ HFNC has been shown to increase end-expiratory lung volumes and reduce respiratory rate in infants with bronchiolitis, and may be better tolerated than nCPAP. ${ }^{[2,27]}$ However, systematic reviews have not yielded conclusive results as to whether either technique reduces intubation rates, largely due to a lack of prospective randomised controlled trials. ${ }^{[2,28]}$

Even though there have been varying reports, there has been no consensus with regard to appropriate invasive mechanical ventilation strategies for infants with severe bronchiolitis. Pressure control or pressureregulated volume-controlled ventilation compared with volume-controlled ventila- tion, may deliver lower tidal volumes than those programmed in high resistance situations, leading to hypoventilation; ${ }^{[29]}$ therefore, volume-controlled modes should be considered in children with bronchiolitis.

Lung-protective ventilation, using a low tidal volume pressure-limited approach, is essential to limit ventilator-induced lung injury ${ }^{[30]}$ In an animal model of RSV RTI, low tidal volume mechanical ventilation caused less ventilation-induced cellular and cytokine influx into the bronchoalveolar space. ${ }^{[31]}$ The key features of lung-protective ventilation are:

- controlled oxygen exposure

- permissive hypercapnia

- low tidal volumes $(4-6 \mathrm{~mL} / \mathrm{kg})$

- adequate (but not excessive) positive endexpiratory pressure

- maintaining peak inspiratory pressures of $<30 \mathrm{cmH}_{2} \mathrm{O}$

Infants with bronchiolitis may have a variety of clinical presentations, which may require different ventilatory approaches (Fig. 1). ${ }^{[25,29,32]}$ Children may predominantly present with apnoeas, air trapping and wheeze, atelectasis and parenchymal disease (in acute respiratory distress syndrome), or a combination of these. ${ }^{[25]}$

\section{Other therapies}

Recombinant human deoxyribonuclease (rhDNAse (Pulmozyme) $)^{[33]}$ and glucocorticoids ${ }^{[34]}$ are not recommended in the management of infants and children with bronchiolitis. Recommendations for the use of exogenous surfactant and heliox therapy are presented in Table 2.

\section{Conclusion}

Most cases of bronchiolitis in young infants and children are mild enough to manage conservatively at home or in general hospital wards. In exceptional cases, acute viral bronchiolitis may be so severe that it warrants admission of patients to the PICU for respiratory support and medical care.

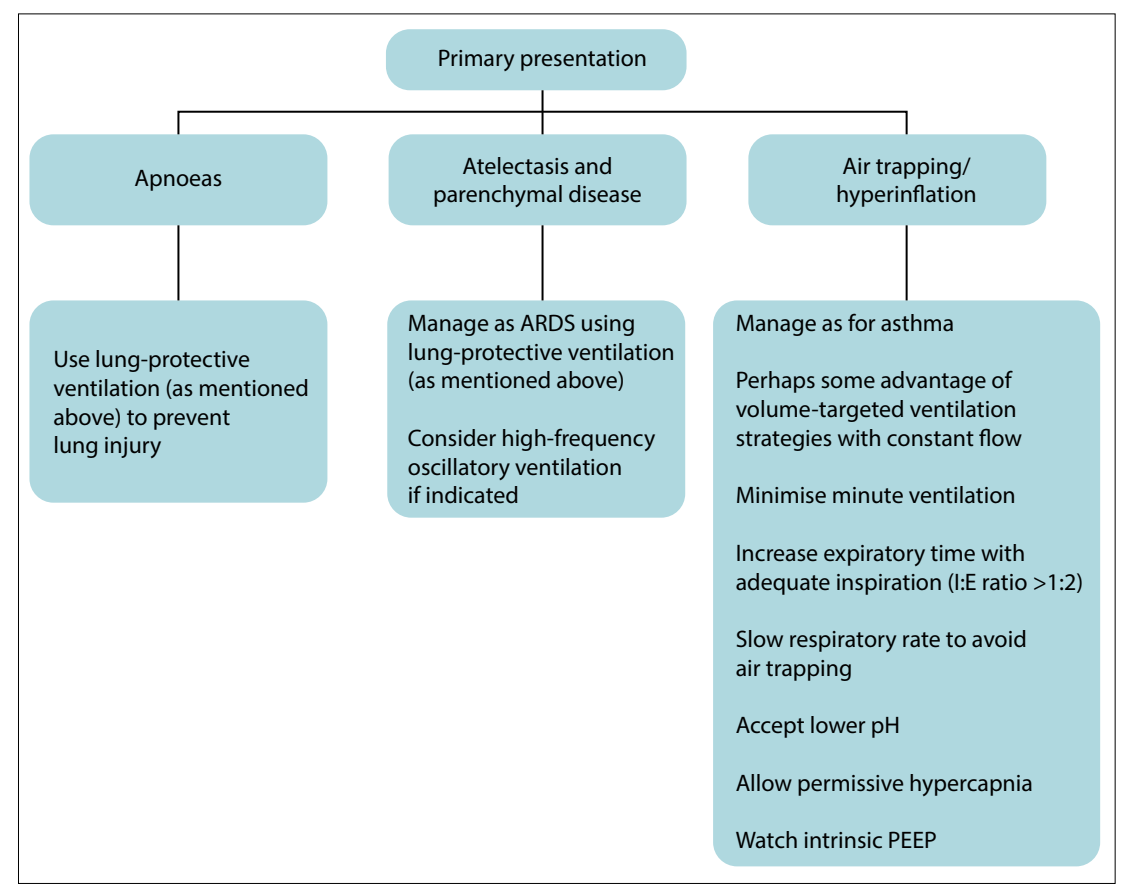

Fig. 1. Invasive ventilation strategies for different presentations of severe bronchiolitis. (ARDS = acute respiratory distress syndrome; $P E E P=$ positive end-expiratory pressure; $I: E=$ inspiration:expiration.)

Table 2. Additional therapy in severe bronchiolitis

\begin{tabular}{lll}
\hline Therapy & Effect & Practice recommendation \\
\hline Exogenous surfactant $^{[34]}$ & $\begin{array}{l}\text { Reduces PICU length of stay } \\
\text { Favourable effects on oxygenation and } \mathrm{CO}_{2} \text { elimination }\end{array}$ & $\begin{array}{l}\text { Exogenous surfactant may be useful in selected patients } \\
\text { Larger trials needed before surfactant can be } \\
\text { recommended as standard treatment }\end{array}$ \\
Heliox $^{[35]}$ & $\begin{array}{l}\text { If delivered effectively (only with tightly fitted facemask } \\
\text { or CPAP), heliox therapy significantly reduced length } \\
\text { of hospital treatment at different points of care (wards, } \\
\text { PICU) }\end{array}$ & $\begin{array}{l}\text { Heliox therapy could be considered for hospitalised infants } \\
\text { with bronchiolitis, hypoxaemia and/or respiratory distress } \\
\text { Nasal cannula heliox therapy is ineffective } \\
\text { RSV-positive infants responded better to heliox therapy }\end{array}$ \\
& $\begin{array}{l}\text { targeted to those who are RSV positive } \\
\text { Heliox therapy should only be delivered via a tight-fitting } \\
\text { non-rebreathing facemask or CPAP }\end{array}$
\end{tabular}




\section{References}

1. Deshpande SA, Northern V. The clinical and health economic burden of respiratory syncytial virus disease among children under 2 years of age in a defined geographical area. Arch Dis Child 2003;88(12):1065-1069. DOI:10.1136/adc.88.12.1065

2. Hall CB, Weinberg GA, Iwane MK, et al. The burden of respiratory syncytial virus infection in young children. N Engl J Med 2009;360(6):588-598. DOI:10.1056/NEJMoa0804877

3. Hall $\mathrm{CB}$, Weinberg GA, Blumkin $\mathrm{AK}$, et al. Respiratory syncytial virus-associated hospitalizations Hall CB, Weinberg GA, Blumkin AK, et al. Respiratory syncytial virus-associated hospitalizations
among children less than 24 months of age. Pediatrics 2013;132(2):e341-e348. DOI:10.1542/ peds.2013-0303

4. Oymar K, Skjerven HO, Mikalsen IB. Acute bronchiolitis in infants, a review. Scand J Trauma Resusc Emerg Med 2014;22:23. DOI:10.7241-22-23

5. Ghani AS, Morrow BM, Hardie DR, Argent AC. An investigation into the prevalence and outcome of patients admitted to a pediatric intensive care unit with viral respiratory tract infections in Cape Tow South Africa. Pediatr Crit Care Med 2012;13(5):e275-e281. DOI:10.1097/PCC.0b013e3182417848

6. Lonngren C, Morrow BM, Haynes S, Yusri T, Vyas H, Argent AC. North-South divide: Distribution and outcome of respiratory viral infections in paediatric intensive care units in Cape Town (South Africa) and Nottingham (United Kingdom). J Paediatr Child Health 2014;50(3):208-215. DOI:10.1111/jpc.12458 7. Hayden FG. Rhinovirus and the lower respiratory tract. Rev Med Virol 2004;14(1):17-31. DOI:10.1002/rmvv.406

8. Louie JK, Roy-Burman A, Guardia-Labar L, et al. Rhinovirus associated with severe lower respiratory tract infections in children. Pediatr Infect Dis J 2009;28(4):337-339. DOI:10.1097/ INF.0b013e31818ffclb

9. Delgado-Corcoran C, Witte MK, Ampofo K, Castillo R, Bodily S, Bratton SL. The impact of human rhinovirus infection in pediatric patients undergoing heart surgery. Pediatr Cardiol 2014;35(8):13871394. DOI:10.1007/s00246-014-0941-3

10. Jartti T, Korppi M. Rhinovirus-induced bronchiolitis and asthma development. Pediatr Allergy Immunol 2011;22(4):350-355. DOI:10.1111/j.1399-3038.2011.01170.x

11. Madhi SA, Ludewick H, Abed Y, Klugman KP, Boivin G. Human metapneumovirus-associated lower respiratory tract infections among hospitalized human immunodeficiency virus type 1 (HIV-1)-infected and HIV-1-uninfected African infants. Clin Infect Dis 2003;37(12):1705-1710. DOI:10.1086/37977112.

12. Morrow BM, Hatherill M, Smuts HE, Yeats J, Pitcher R, Argent AC. Clinical course of hospitalised children infected with human metapneumovirus and respiratory syncytial virus. J Paediatr Child Health 2006;42(4):174-178. DOI:10.1111/j.1440-1754.2006.00825.x

13. Hatherill M, Levin M, Lawrenson J, Hsiao NY, Reynolds L, Argent A. Evolution of an adenovirus outbreak in a multidisciplinary children's hospital. J Paediatr Child Health 2004;40(8):449-454. DOI:10.1111/j.1440-1754.2004.00426.x

14. Madhi SA, Ismail K, O’Reilly C, Cutland C. Importance of nosocomial respiratory syncytial virus infection in an African setting. Trop Med Int Health 2004; $9(4): 491-498$. DOI:10.1111/.1365-3156.2004.01221.x

15. Aitken C, Jeffries DJ. Nosocomial spread of viral disease. Clin Microbiol Rev 2001:14(3):528-546. Aitken C, Jeffries DJ. Nosocomial sp
DOI:10.1128/CMR.14.3.528-546.2001

16. Vaideeswar P, Bavdekar SB, Biswas P, Sarangarajan R, Bhosale A. Viral ventilator-associated pneumonia: Uncovering tip of the iceberg. Indian J Pathol Microbiol 2011;54(2):339-343. DOI:10.4103/0377-4929.81633
17. Pavia AT. Viral infections of the lower respiratory tract: Old viruses, new viruses, and the role of diagnosis. Clin Infect Dis 2011;52(Suppl 4):S284-S289. DOI:10.1093/cid/cir043

18. Nagakumar P, Doull I. Current therapy for bronchiolitis. Arch Dis Child 2012;97(9):827-830. DOI:10.1136/archdischild-2011-301579

19. Downes IJ, Wood DW, Striker TW, Haddad C. Acute respiratory failure in infants with bronchiolitis. Anesthesiology 1968;29(3):426-434. DOI:10.1097/00000542-196805000-00008

20. Principi T, Fraser DD, Morrison GC, et al. Complications of mechanical ventilation in the pediatric population. Pediatr Pulmonol 2010;46(5):452-457.DOI:10.1002/ppul.21389

21. Hennus MP, van Vught AJ, Brabander M, Brus F, Jansen NJ, Bont LJ. Mechanical ventilation drives inflammation in severe viral bronchiolitis. PLoS One 2013;8(12):e83035. DOI: 10.1371/journal.pone.0083035
ing 22. Donlan M, Fontela PS, Puligandla PS. Use of continuous positive airway pressure (CPAP) in acute viral bronchiolitis: A systematic review. Pediatr Pulmonol 2011;46(8):736-746. DOI:10.1002/ppul.21483

23. Argent AC, Biban P. What's new on NIV in the PICU: Does everyone in respiratory failure requir endotracheal intubation? Intensive Care Med 2014;40(6):880-884. DOI:10.1007/s00134-014-3274-Z

24. Lazner MR, Basu AP, Klonin H. Non-invasive ventilation for severe bronchiolitis: Analysis an evidence. Pediatr Pulmonol 2012;47(9):909-916. DOI:10.1002/ppul.22513

25. Greenough A. Role of ventilation in RSV disease: CPAP, ventilation, HFO, ECMO. Paediatr Respir Rev 2009;10(Suppl 1):26-28. DOI:10.1016/S1526-0542(09)70012-0

26. Hough JL, Pham TM, Schibler A. Physiologic effect of high-flow nasal cannula in infants wit bronchiolitis. Pediatr Crit Care Med 2014;15(5):e214-e219. DOI:10.1097/PCC.0000000000000112

27. Abboud PA, Roth PJ, Skiles CL, Stolfi A, Rowin ME. Predictors of failure in infants with vira bronchiolitis treated with high-flow, high-humidity nasal cannula therapy. Pediatr Crit Care Med 2012;13(6):e343-e349. DOI:10.1097/PCC.0b013e31825b546f

28. Beggs S, Wong ZH, Kaul S, Ogden KJ, Walters JA. High-flow nasal cannula therapy for infants with Beggs S, Wong ZH, Kaul S, Ogden K, Walters JA. High-flow nasal cannula therapy for infants with
bronchiolitis. Cochrane Database Syst Rev 2014;1:CD009609. DOI:10.1002/14651858.cd009609.pub2 29. Medina A, Modesto-Alapont V, Lobete C, et al. Is pressure-regulated volume control mode appropriate for severely obstructed patients? J Crit Care 2014;29(6):1041-1045. DOI:10.1016/j.jcrc.2014.07.006

for severely obstructed patients? J Crit Care 2014;29(6):1041-1045. DOI:10.1016/j.jcrc.2014.07.006
30. Turner DA, Arnold JH. Insights in pediatric ventilation: Timing of intubation, ventilatory strategies, . Turner DA, Arnold JH. Insights in pediatric ventilation: Timing of intubation, ventilatory st
and weaning. Curr Opin Crit Care 2007;13(1):57-63. DOI:10.1097/MCC.0b013e32801297f9

31. Hennus MP, Bont LJ, Jansen NJ, van Vught AJ. Tidal volume drives inflammation during mechanical ventilation for viral respiratory infection. Pediatr Crit Care Med 2014;15(1):e27-e31. DOI:10.1097/01 pcc.0000436197.07713.30

32. Rose L. Clinical application of ventilator modes: Ventilatory strategies for lung protection. Aust Crit Care 2010;23(2):71-80. DOI:10.1016/j.aucc.2010.03.003

33. Enriquez A, Chu IW, Mellis C, Lin WY. Nebulised deoxyribonuclease for viral bronchiolitis in children younger than 24 months. Cochrane Database Syst Rev 2012;11:CD008395. DOI:10.1002/14651858.cd008395.pub2

34. Jat KR, Chawla D. Surfactant therapy for bronchiolitis in critically ill infants. Cochrane Database Syst Rev 2012;9:CD009194. DOI:10.1002/14651858.cd009194.pub2

35. Chowdhury MM, McKenzie SA, Pearson CC, et al. Heliox therapy in bronchiolitis: Phase III multicenter double-blind randomized controlled trial. Pediatrics 2013;131(4):661-669. DOI:10.1542 peds.2012-1317 